How to cite: Maradin, M. (2020) Parallel Analysis of Monthly Precipitation Series and Drought Indices in Croatia (1951-2010). 2020 "Air and Water - Components of the Environment" Conference Proceedings, Cluj-Napoca, Romania, p. 223-234, DOI: 10.24193/AWC2020_21.

\title{
PARALLEL ANALYSIS OF MONTHLY PRECIPITATION SERIES AND DROUGHT INDICES IN CROATIA (1951-2010)
}

\author{
Mladen MARADIN ${ }^{1}$
}

DOI: 10.24193/AWC2020_21

\begin{abstract}
This paper deals with the parallel analysis of monthly precipitation series and drought indices in Croatia for the 1951-2010 period. The monthly precipitation amounts for the nine meteorological stations that are representing the majority of climate types in Croatia were used. In order to determine the precipitation variability features and the drought occurrence frequency, the analysis was conducted over four 30-year periods (1951-1980, 1961-1990, 1971-2000 and 1981-2010). As a measure of drought, the Standardized Precipitation Index (SPI) and the Rainfall Anomaly Index (RAI) were used. The precipitation amount decrease and the variability increase were determined for many of the analysed stations, but there are significant regional and seasonal differences. Using RAI and SPI6 several drought episodes in the research period were determined. The drought occurrence in the warm part of the year (April to September) that corresponds to the vegetation period in Croatia was analysed.
\end{abstract}

Keywords: drought, precipitation variability, drought indices, Croatia

\section{INTRODUCTION}

Drought is a natural phenomenon that has major ecological, economic, social and political impact and can occur in almost all climatic zones. Although the economic impact of drought on agriculture is most often analysed, it has many other social impacts. There are many types of droughts, due to their origin - meteorological, agricultural, hydrological, ground-water, stream-flow and socio-economic drought (Lloyd-Hughes and Saunders, 2002; Espinosa, 2019). The meteorological drought, that is caused by precipitation deficiency over some prolonged period (Martins et al, 2012; Potop et al., 2014; Salehnia et al, 2017), will be analysed in this paper. In Europe, the drought is a usual phenomenon in the southern (Mediterranean area) and southeastern part of the continent, but there were droughts in 1989, 1991 and 2003 that had impacted all the areas of Europe (Blenkinsop and Fowler, 2007; Tadić et al, 2015). In the Mediterranean area drought is most often in the warm part of the year, due to precipitation amount minimum in the summer months. On the Croatian coast, it is usually July. There have been many papers that deal with the occurrence of the drought

\footnotetext{
${ }^{1}$ Department of Geography, Faculty of Science, University of Zagreb, Marulićev trg 19/II, 10000 Zagreb, Croatia,mmaradin@geog.pmf.hr
} 
in the Mediterranean area (Bordi et al., 2001; Blenkinsop and Fowler, 2007; Livada and Assimakopoulos, 2007; Martins et al., 2012; Potop et al., 2014). In several studies, the relationship between precipitation variability and drought occurrence were analysed (Martins et al., 2012; Liu et al., 2017; Ayanlade et al., 2018). In many of these studies, the decrease of precipitation is connected to the irregularities in hydrological regimes and consequently, the affected areas become more prone to droughts.

In Croatia drought has been addressed as a part of the climate change issue, as well as a natural risk. Drought can occur in any part of Croatia, but it often occurs in the southern part of the coastal region of Croatia and the eastern part of the country. As the eastern part of the country is mainly an agricultural area, this can have a major impact on the part of the economy that is related to the agriculture (Perčec Tadić et al., 2014; Ljubenkov and Cindrić Kalin, 2016). Tourism is developing in the coastal part of the country, so the impact of drought on the overall economy is not that significant. Due to an impact on the economy, there are papers dealing with the drought analyses in Croatia. The main objects of the scientific interest are extreme drought episodes as well as drought-prone areas (Cindrić, et al, 2010; Cindrić et al., 2016; Ljubenkov and Bonacci, 2011). Most of studies that deals with the drought are based on meteorological indicators of dry periods analyses and mostly used drought indices in the studies are Standardized Precipitation Index, Aridity Index, Palmer drought index (Cindrić and Kalin, 2012; Cindrić et al., 2010; Cindrić et al., 2016; Gajić-Čapka and Cindrić, 2011; Gajić-Čapka et al., 2015; Perčec Tadić et al., 2014). Several researches deal with drought analyses of regions that are most vulnerable to the drought - eastern (Mihajlović, 2006; Tadić et al., 2015) and southern (Juras, and Cindrić, 2009; Ljubenkov and Bonacci, 2011; Ljubenkov and Cindrić Kalin, 2016) part of Croatia. Just a few papers deal with hydrological indicators of drought (Ljubenkov and Cindrić Kalin, 2016).

The aim of this paper is to analyse monthly precipitation series and drought indices in Croatia for the 1951-2010 period. To determine the precipitation variability features and the drought occurrence frequency, the analysis was conducted over four 30-year periods (1951-1980, 1961-1990, 1971-2000 and 19812010). The SPI6 were also analysed as this is the recommended timescale for agriculture drought and it may be related to the lack of precipitation affecting the water level in rivers and lakes. Most attention is dedicated to the drought occurrence in the warm part of the year (April to September) that corresponds to the vegetation period. The analyses will also be conducted both for the months with high precipitation variability values and for months with a significant increase in precipitation variability.

\section{DATA AND METHODS}

\subsection{Data used}

Monthly precipitation amounts for the nine meteorological and climatological stations for the 1951-2010 period were used to analyse precipitation variability and 
the occurrence of the drought (Table 1). Data were obtained from the Meteorological and Hydrological Service in Zagreb, Croatia.

Table 1. Geographical coordinates of the nine meteorological and climatological stations used in the study

\begin{tabular}{|l|l|l|c|}
\hline \multicolumn{1}{|c|}{ station } & latitude (N) & longitude (E) & altitude (m) \\
\hline Hvar & $43^{\circ} 10^{\prime} 16^{\prime \prime}$ & $16^{\circ} 26^{\prime} 13^{\prime \prime}$ & 20 \\
\hline Ogulin & $45^{\circ} 15^{\prime} 46^{\prime \prime}$ & $15^{\circ} 13^{\prime} 20^{\prime \prime}$ & 328 \\
\hline Osijek & $45^{\circ} 34^{\prime}$ & $18^{\circ} 40^{\prime}$ & 84 \\
\hline Rovinj & $45^{\circ} 06^{\prime}$ & $13^{\circ} 38^{\prime}$ & 20 \\
\hline Slavonski Brod & $45^{\circ} 9^{\prime} 33^{\prime \prime}$ & $17^{\circ} 59^{\prime} 43^{\prime \prime}$ & 88 \\
\hline Split-Marjan & $43^{\circ} 30^{\prime} 30^{\prime \prime}$ & $16^{\circ} 25^{\prime} 35^{\prime \prime}$ & 122 \\
\hline Varaždin & $46^{\circ} 16^{\prime} 58^{\prime \prime}$ & $16^{\circ} 21^{\prime} 50^{\prime \prime}$ & 167 \\
\hline Zadar & $44^{\circ} 7^{\prime} 48^{\prime \prime}$ & $15^{\circ} 12^{\prime} 21^{\prime \prime}$ & 5 \\
\hline Zagreb-Maksimir & $45^{\circ} 49^{\prime} 19^{\prime \prime}$ & $16^{\circ} 2^{\prime} 1^{\prime \prime}$ & 123 \\
\hline
\end{tabular}

Stations are selected in such a way that they are placed equally over Croatia and represent the majority of climate types that occur in Croatia (Fig. 1). According to the Köppen climate classification, the dry season occurs only in the southern coastal part of Croatia. Mediterranean climates (Cs) that are present in that part of the country have dry summers, so there is a high probability of the drought in the summer months.

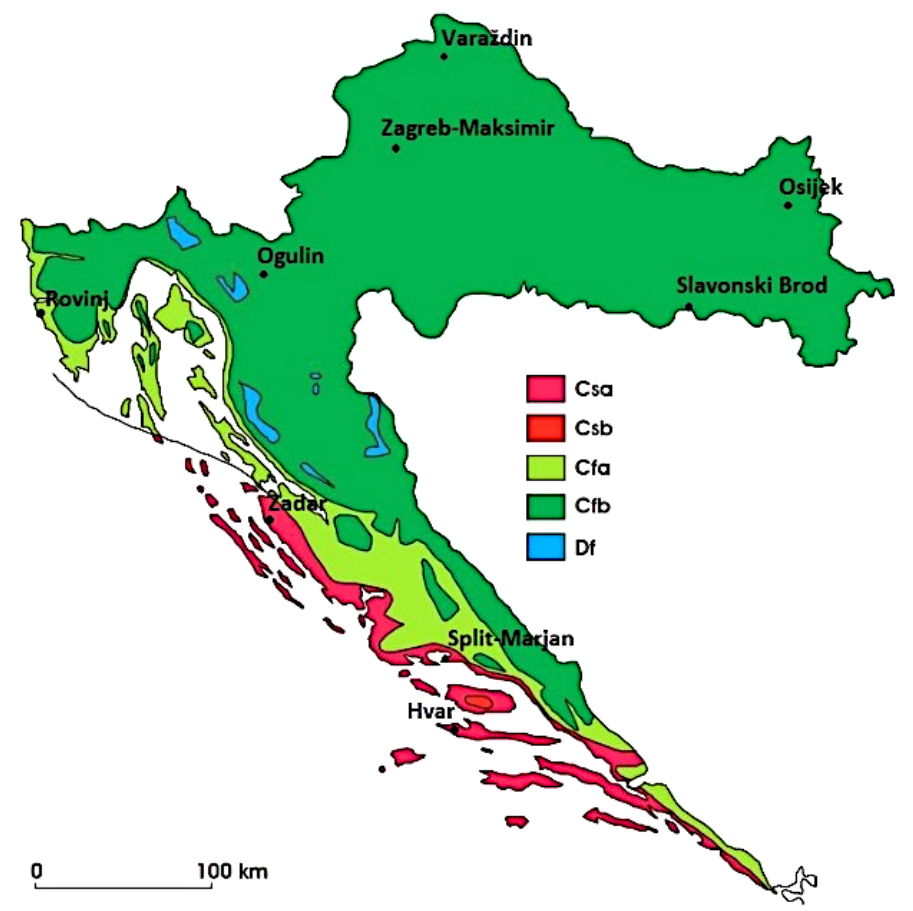

Fig. 1. Meteorological and climatological stations used in the study and the Köppen climate types in Croatia (source: Šegota and Filipčić, 2003). 
There are two types of annual precipitation course - maritime and continental and both are present in Croatia. The Osijek, Slavonski Brod, Varaždin and ZagrebMaksimir stations have continental, and Hvar, Ogulin, Rovinj, Split-Marjan and Zadar stations have maritime type of precipitation course. For the stations with continental precipitation course, the maximum precipitation occurs in a warm part of the year, between April and September, while for the stations with maritime precipitation course maximum precipitation occurs in cold part of the year, between October and March (Fig. 2).

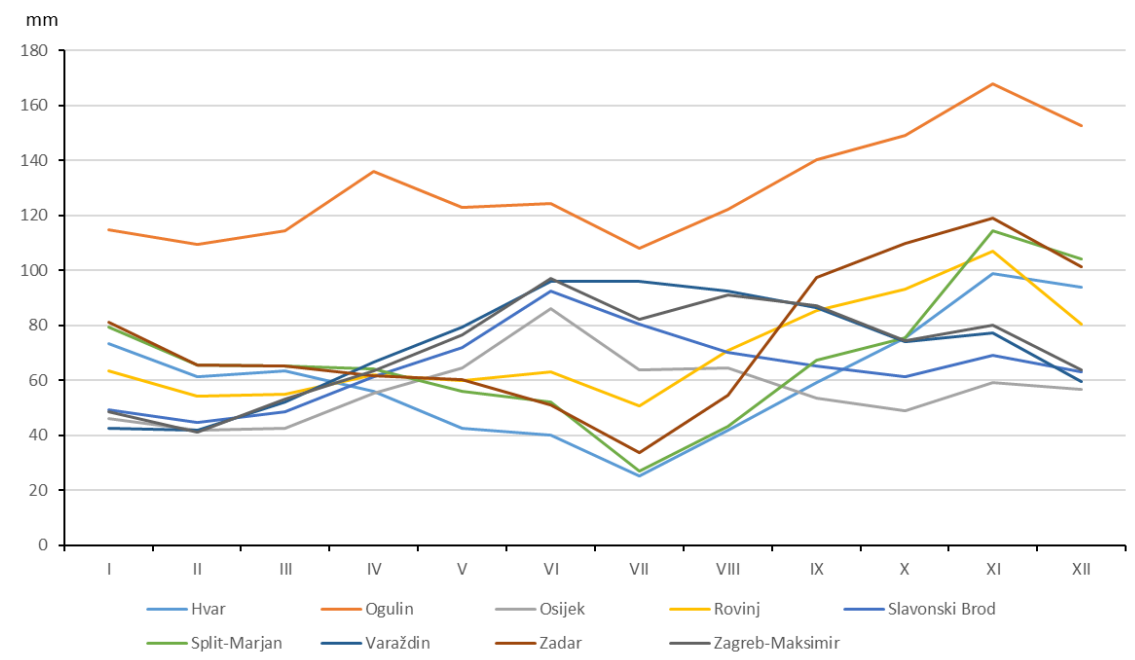

Fig. 2. Annual course of precipitation for analysed stations for 1951-2010 period

\subsection{Methods}

As a measure of precipitation variability, the coefficient of variation (or relative standard deviation) is used. It is defined as the ratio of the standard deviation $(\sigma)$ to the mean value and it is expressed as a percentage. Coefficient of variation is often used as a measure of precipitation variability in many studies in Croatia (Šegota, 1969; Gajić-Čapka, 1982; Juras, 1995; Milković, 1998).

To determine the trend of precipitation, a linear trend was calculated for 30-year periods. The significance of the trend was determined by the Mann-Kendall trend test, which is mostly used for that purpose.

In order to analyse the drought occurrence, the Standardized Precipitation Index (SPI) and Rainfall Anomaly Index (RAI) methods were used. The SPI index is widely used drought index (McKee et al, 1995; Perčec Tadić et al, 2014; Tadić, 2015; Ljubenkov and Cindrić Kalin, 2016, Salehnia et al., 2017) because it is applicable in all climate types (Santos et al., 2010). It is based on the probability of occurrence of a certain deviation from an average amount of precipitation and for a given timescale. It is calculated using a probability density function of the gamma distribution as follow: 


$$
g(p)=\frac{1}{\beta^{\alpha} \Gamma(\alpha)} p^{\alpha-1} e^{\frac{-p}{\beta}} \quad(\mathrm{p}>0),
$$

where $\Gamma(\alpha)$ is the gamma function; $\mathrm{p}(\mathrm{mm})$ is the amount of precipitation $(\mathrm{p}>0) ; \alpha$ is the shape parameter $(\alpha>0)$; and $\beta$ is the scale parameter $(\beta>0)$.

If the SPI is computed at a timescale of $\delta$-month, the variable to be analysed is the monthly precipitation, for $\delta=1$, and the cumulative precipitation in periods of $\delta$ consecutive month, for $\delta>1$ (Salehnia et al., 2017). In the paper, the SPI6 was calculated as this is a recommended timescale for agriculture drought (Hayes et al., 1999 ) and it can be associated with the lack of precipitation that impacts the water level in rivers and lakes (Espinosa et al., 2019).

The RAI considers two anomalies, i.e., positive anomaly and negative anomaly. First, the precipitation data are arranged in descending order. Then ten highest values are averaged to form a threshold for positive anomaly and ten lowest values are averaged to form a threshold for negative anomaly. The thresholds are calculated using the equation (Salehnia et al., 2017):

$$
P= \pm 3 \frac{p-\bar{p}}{\bar{m}-\bar{p}},
$$

where $\mathrm{p}$ is the precipitation amount for each year $(\mathrm{mm}) ; \bar{p}$ is the long-term average precipitation (mm); and $\bar{m}$ is the average of the ten highest values of $\mathrm{p}$ for the positive anomaly and the average of the ten lowest values of $p$ for the negative anomaly.

SPI and RAI were calculated using the MDM (Meteorological Drought Monitor) software application developed by AgriMetSoft for calculating meteorological drought indices.

The SPI and RAI values are categorized corresponding to drought intensity proposed by McKee et al. (1993) and Salehnia et al. (2017), respectively, and presented in Table 2. A drought event occurs any time the SPI and RAI are continuously negative and reaches an intensity of -1 and $-1,2$ or less, respectively.

Table 2. Drought classification according to SPI and RAI

\begin{tabular}{|l|l||l|l|}
\hline class & SPI & class & RAI \\
\hline extremely wet & $\geq 2.00$ & extremely wet & $\geq 0.3$ \\
\hline very wet & $1.50-1.99$ & & \\
\hline moderately wet & $1.00-1.49$ & moderately wet & $0.3--0.3$ \\
\hline normal & $0.99--0.99$ & normal & $-0.3--1.2$ \\
\hline moderately dry & $-1.00--1.49$ & moderately dry & $-1.2--2.1$ \\
\hline severely dry & $-1.50--1.99$ & severely dry & $-2.1--3.0$ \\
\hline extremely dry & $\leq-2.00$ & extremely dry & $\leq-3.0$ \\
\hline
\end{tabular}

After the SPI is calculated the number of years with the drought events is calculated for each of four 30-year periods (1951-1980, 1961-1990, 1971-2000 and 1981-2010). Also, a change in precipitation variability was determined for each 30year period to analyse the relationship between precipitation variability and drought 
occurrence change. Since drought is most pronounced in the warm part of the year and summer, the analyses in this study will focus mainly on that part of the year.

\section{RESULTS AND DISCUSSIONS}

\subsection{Trend analyses}

Trend analyses of the precipitation amount changes for the 1951-2010 period show that most stations have experienced a decrease in precipitation, although there are significant regional and monthly differences (Table 3). Precipitation amount decreased in July (statistically significant in Hvar and Rovinj) and increased in September (statistically significant in Slavonski Brod). Apart from the decrease in precipitation amount in Varaždin in May, there is no other statistically significant trend in precipitation change. Since for most of the months in the warm part of the year, the precipitation amount decreased and there is a greater sensitivity on drought occurrence in that part of the year, the analyses will focus on that period.

Table 3. Linear trend changes of monthly and annual precipitation amount (mm per year) for researched stations for 1951-2010 period

\begin{tabular}{|l|c|c|c|c|c|c|c|c|c|c|c|c|c|}
\hline & I & II & III & IV & V & VI & VII & VIII & IX & $\mathbf{X}$ & $\mathbf{X I}$ & XII & YEAR \\
\hline Hvar & -0.31 & -0.40 & 0.10 & 0.01 & -0.09 & 0.27 & $-\mathbf{0 . 2 4}$ & 0.34 & 0.03 & 0.21 & -0.11 & 0.16 & -0.02 \\
\hline Ogulin & -0.46 & -0.31 & -0.37 & 0.02 & -0.58 & 0.12 & -0.46 & -0.29 & 0.69 & 0.07 & -0.21 & 0.39 & -1.38 \\
\hline Osijek & -0.03 & -0.36 & -0.01 & -0.15 & -0.12 & 0.12 & -0.24 & 0.43 & 0.56 & 0.29 & 0.13 & -0.22 & 0.40 \\
\hline Rovinj & -0.29 & -0.45 & -0.25 & 0.03 & 0.04 & 0.27 & -0.70 & 0.09 & 0.28 & -0.25 & 0.07 & 0.11 & -1.03 \\
\hline $\begin{array}{l}\text { Slavonski } \\
\text { Brod }\end{array}$ & 0.21 & -0.42 & 0.08 & 0.04 & -0.23 & -0.25 & -0.15 & 0.08 & $\mathbf{0 . 7 0}$ & 0.33 & 0.02 & -0.34 & 0.05 \\
\hline $\begin{array}{l}\text { Split- } \\
\text { Marjan }\end{array}$ & -0.05 & -0.12 & -0.02 & 0.05 & 0.02 & -0.02 & -0.33 & 0.00 & 0.51 & 0.08 & -0.01 & -0.53 & -0.43 \\
\hline Varaždin & -0.23 & -0.15 & 0.14 & -0.16 & $-\mathbf{0 . 7 5}$ & -0.21 & -0.63 & -0.08 & 0.59 & 0.19 & -0.44 & -0.10 & -1.83 \\
\hline Zadar & -0.16 & -0.21 & -0.24 & 0.24 & 0.13 & -0.14 & -0.29 & -0.18 & 0.49 & -0.85 & -0.42 & -0.03 & -1.66 \\
\hline $\begin{array}{l}\text { Zagreb- } \\
\text { Maksimir }\end{array}$ & -0.21 & -0.15 & 0.03 & 0.00 & -0.61 & -0.38 & -0.40 & 0.41 & 0.29 & 0.35 & -0.05 & -0.14 & -0.86 \\
\hline
\end{tabular}

Note: bolded values mark the significant trend change at level $\alpha=0,05$

\subsection{The drought episodes in 1951-2010 period}

The drought analysis for the 1951-2010 period using RAI shows that the droughts occurred during the summer months in the most stations (Fig. 3). Droughts were most often present only in a part of the country, although the impact of the extreme and widespread droughts can be detected. In July, significant episodes of the 1989 drought could be observed in all researched stations, and in August the droughts of 1962 and 2000 are even more visible. Although similar drought episodes could have been determined for almost all months of the year, these months were presented because then the precipitation minimum and precipitation variability maximum 
occur in most stations in Croatia (Maradin et al., 2014). Although drought can occur in July and August due to precipitation features, it is interesting to note that there have been many years with extreme wet events in these months.

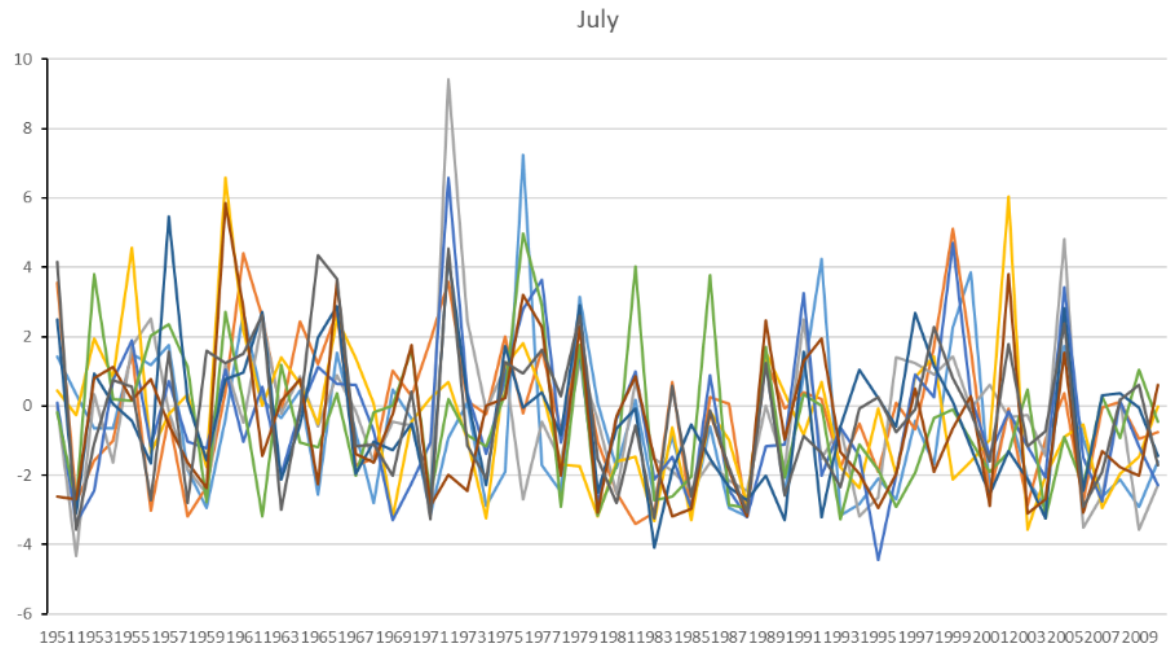

— Hvar — Ogulin — Osijek — Rovinj — Slavonski Brod — Split-Marjan — Varaždin — Zadar —Zagreb-Maksimir

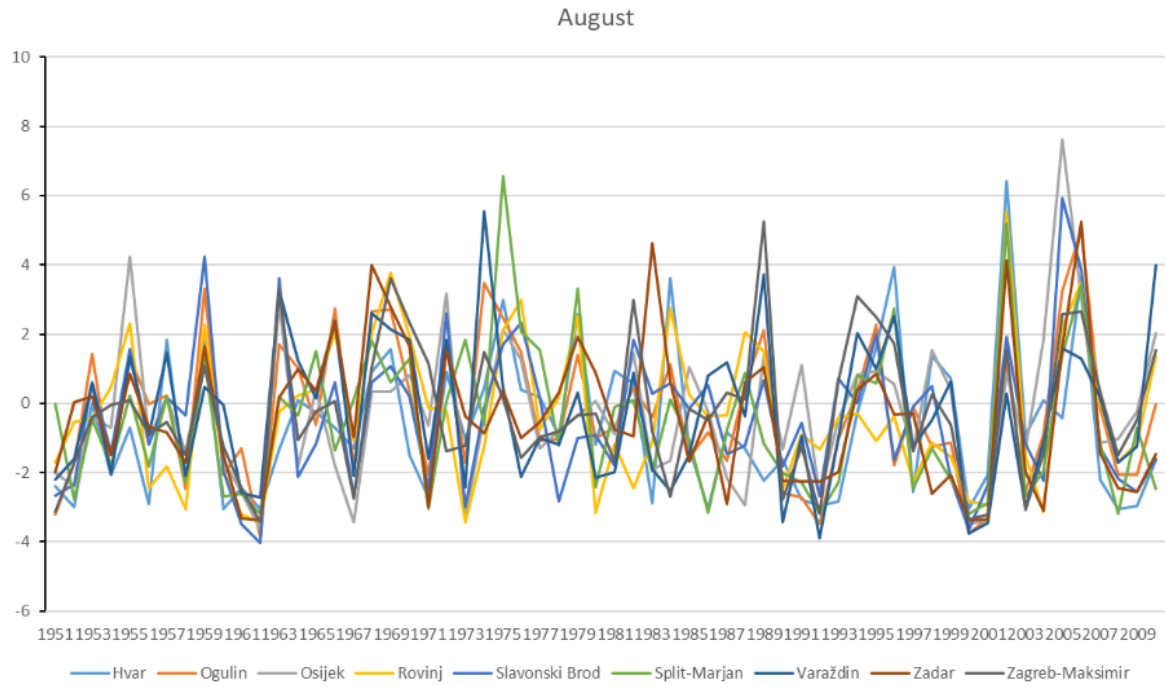

Fig. 3. RAI in the July and August for the researched stations for the 1951-2010 period

To compare the reliability of the RAI as a drought indicator, the SPI6 for September have been determined, because it can be used as an indicator of wetness in vegetation period from April till September (Fig. 4). SPI6 refers to the precipitation accumulation period of 6 months that, in this example, ends in September. This indicator identifies drought episodes that could have a significant impact on agriculture in the years 1952, 1962, 1992, 2000 and 2003 for most of used stations. These results are somewhat consistent with the results obtained by the RAI. 
The threshold of the category extremely dry was exceeded only for the Varaždin station in 1992.

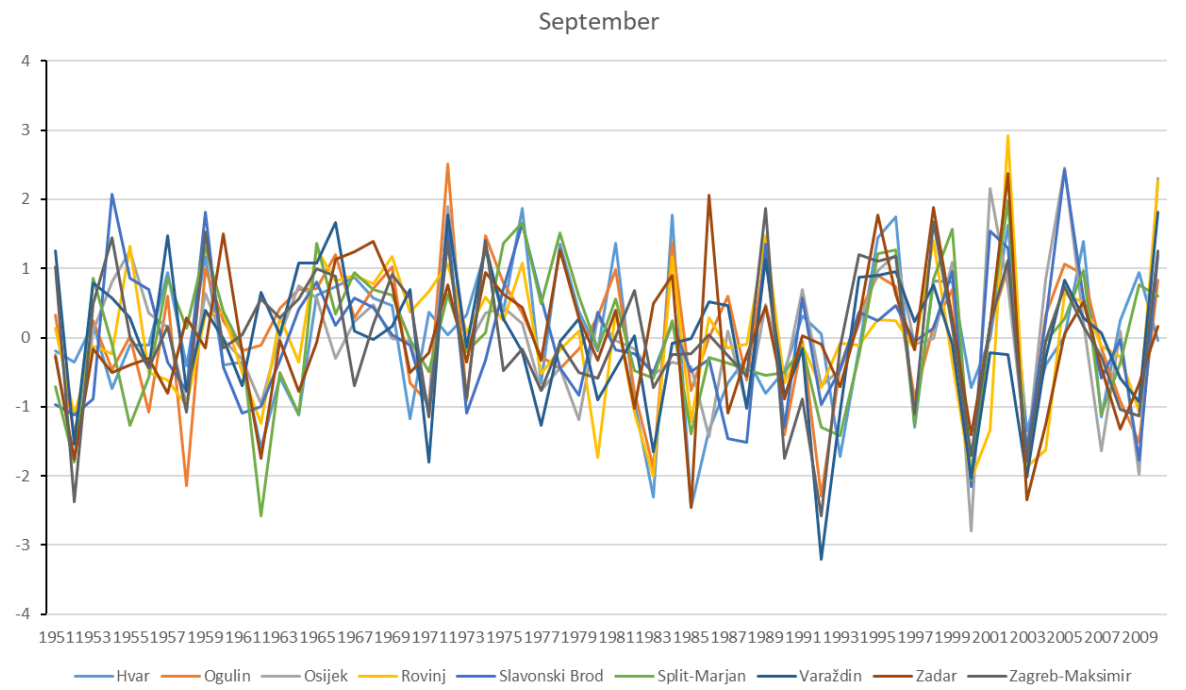

Fig. 4. SPI6 in the September for the researched stations for the 1951-2010 period

\subsection{Analysis of the precipitation variability and drought occurrence}

The SPI and coefficient of variation for four 30-year periods were calculated to determine the relationship between precipitation variability and the drought occurrence. Many studies already establish the fact that the variability of the precipitation would increase due to current or predicted climate change (O'Gorman and Schneider, 2009; Martins et al., 2012). In this study, the precipitation variability increase could be expected as a result of a precipitation amount decrease for most of the stations. As an average precipitation decrease, the similar absolute changes from year to year can lead to the higher values of precipitation variability.

The values of precipitation variability show an overall increase for most of the stations (Tables 4 and 5). This increase is more pronounced for the warm part of the year than for the annual variability values. Consecutive increase in annual precipitation variability for 30-year periods is generally determined for the Hvar, Osijek, Rovinj and Split-Marjan stations, and for the warm part of the year, it is determined for all the station except Ogulin station. This may be since the decrease in precipitation has more effect on the variability in stations with a relatively small amount of precipitation. Therefore, as the Ogulin station has the highest precipitation amounts of all analysed stations, no increase in precipitation variability for that station was established. To find the cause for this, further analyses of the factors affecting precipitation change and variability need to be conducted.

To determine the occurrence of the drought, all the years with the dry conditions (extremely dry, severely dry and moderately dry events according to the SPI) were summed for each 30-year period. The total number of months included in the 
analysis in each 30-year period is 360 for annual and 180 for a warm part of the year analysis (Table 4 and 5). The annual drought occurrence ranges from 41 (11.4\% of the total of 360 months) in Varaždin for the 1951-1980 period to 70 (19.4\%) in Hvar for the 1981-2010 period. The drought occurrence in a warm part of the year ranges from 17 (9.4\% of the total of 180 months) in Varaždin for the 1951-1980 period to 36 (20.0\%) for both Hvar and Varaždin for 1981-2010 period. The range is larger for the warm part of the year as expected, but it is important to note that Varaždin is the station with the lowest and highest drought occurrence for the warm part of the year (though for different 30-year periods). This confirms the fact that droughts can occur in any part of Croatia.

Table 4. Annual values of precipitation variability - VAR (\%) and drought occurrence - DRO for four 30-year periods for analysed stations ( $N=360$ months)

\begin{tabular}{|c|c|c|c|c|c|c|c|c|c|}
\hline VAR & Hvar & Ogulin & Osijek & Rovinj & $\begin{array}{c}\text { Slavonski } \\
\text { Brod }\end{array}$ & $\begin{array}{c}\text { Split- } \\
\text { Marjan }\end{array}$ & Varaždin & Zadar & $\begin{array}{c}\text { Zagreb- } \\
\text { Maksimir }\end{array}$ \\
\hline $1951-1980$ & 15.8 & 15.4 & 16.7 & 16.6 & 17.9 & 14.3 & 17.0 & 19.9 & 16.6 \\
\hline $1961-1990$ & 20.5 & 16.1 & 15.5 & 17.6 & 14.4 & 16.4 & 17.8 & 19.5 & 15.7 \\
\hline $1971-2000$ & 22.5 & 15.8 & 19.2 & 16.0 & 15.7 & 20.0 & 16.0 & 17.0 & 15.0 \\
\hline $1981-2010$ & 23.6 & 13.1 & 23.1 & 23.1 & 16.4 & 21.2 & 15.8 & 18.5 & 13.3 \\
\hline DRO & \multicolumn{7}{|l|}{} \\
\hline 1951-1980 & 46 & 46 & 49 & 48 & 54 & 49 & 41 & 43 & 50 \\
\hline $1961-1990$ & 56 & 48 & 55 & 47 & 60 & 50 & 44 & 57 & 57 \\
\hline $1971-2000$ & 63 & 54 & 54 & 51 & 56 & 61 & 54 & 55 & 61 \\
\hline $1981-2010$ & 70 & 58 & 57 & 58 & 53 & 65 & 66 & 66 & 63 \\
\hline
\end{tabular}

Table 5. Values of precipitation variability - VAR (\%) and drought occurrence - DRO in warm part of the year (from April to September) for four 30-year periods for analysed stations ( $N=180$ months)

\begin{tabular}{|c|c|c|c|c|c|c|c|c|c|}
\hline VAR & Hvar & Ogulin & Osijek & Rovinj & $\begin{array}{c}\text { Slavonski } \\
\text { Brod }\end{array}$ & $\begin{array}{c}\text { Split- } \\
\text { Marjan }\end{array}$ & Varaždin & Zadar & $\begin{array}{l}\text { Zagreb- } \\
\text { Maksimir }\end{array}$ \\
\hline $1951-1980$ & 29.1 & 20.8 & 20.4 & 21.3 & 21.9 & 29.7 & 21.6 & 25.1 & 20.8 \\
\hline $1961-1990$ & 39.4 & 21.6 & 19.2 & 24.0 & 20.1 & 28.6 & 21.9 & 28.5 & 19.7 \\
\hline $1971-2000$ & 40.7 & 25.1 & 24.1 & 24.7 & 21.3 & 32.0 & 25.7 & 29.0 & 25.7 \\
\hline $1981-2010$ & 42.6 & 23.6 & 33.2 & 35.1 & 24.7 & 34.1 & 25.2 & 36.2 & 25.7 \\
\hline \multicolumn{10}{|l|}{ DRO } \\
\hline $1951-1980$ & 21 & 21 & 19 & 26 & 27 & 27 & 17 & 20 & 26 \\
\hline 1961-1990 & 22 & 20 & 22 & 23 & 28 & 25 & 21 & 24 & 28 \\
\hline $1971-2000$ & 28 & 24 & 24 & 25 & 26 & 28 & 27 & 20 & 30 \\
\hline $1981-2010$ & 36 & 27 & 29 & 29 & 25 & 30 & 36 & 27 & 32 \\
\hline
\end{tabular}

The values of drought occurrence show that the drought signal is much clearer than the signal of precipitation variability change (Tables 4 and 5). Most stations show an increase in the drought for annual values as well as for the warm part of the year. Even in the stations where the variability decreases, the drought occurrence increase. The only exception is Slavonski Brod station, where the annual values of drought events decrease as well as in the warm part of the year. Furthermore, despite the increase in precipitation variability in the warm part of the year, the number of 
drought decrease. But it must be noted that in this case there is no significant decrease of drought, especially in the warm part of the year (27-28-26-25 for each 30-year period).

Although it was not possible to present monthly changes in the precipitation variability and SPI here, they show even more inconsistencies. For example, the increase of precipitation variability and increase of drought occurrence for August is determined for the Hvar, Ogulin, Split-Marjan, Varaždin and Zagreb-Maksimir stations. In the other stations, the increase in variability was, in general, determined, but there were no significant changes in drought occurrence. Only at the Slavonski Brod station, there has been a clear decrease in the number of drought occurrence. These unclear results may be result of usage of 30-year period, which is by some authors (Tadić et al., 2015) minimal period for the SPI application. We may assume that more reliable results could be obtained if the longer periods (40- or 50-year) were used.

The results obtained in this study correspond to similar studies that also found a decrease in precipitation amounts and an increase in drought occurrence in Croatia (Cindrić et al., 2010; Perčec Tadić et al., 2014; Gajić-Čapka et al., 2015). However, this relationship is complex and there are numerous regional and seasonal differences, so more detailed researches are needed to identify all the factors that affect it. It is important to note that an increase of the precipitation variability may also be due to an increase in extreme wet episodes (more in intensity than in frequency), so increase in variability may not correspond to an increase in drought occurrence. Due to the impact of drought on the economy, this relationship needs to be further researched with particular emphasis on local drought-prone areas.

\section{CONCLUSIONS}

The paper analyses the relationship between changes in precipitation variability and the drought occurrence using monthly data of precipitation amounts for nine meteorological and climatological stations in Croatia for the 1951-2010 period. The coefficient of variation was used as an indicator of the precipitation variability and SPI and RAI were used as an indicator of drought. This paper mainly analysed changes in the warm part of the year. Several drought episodes were determined in the research period using RAI and SPI6.

The increase in precipitation variability, as well as increase in drought occurrence, were determined for most researched stations, but there were stations where despite the variability increase the drought occurrence decreased, and vice versa. To determine a more significant relationship between changes in researched variables, a larger number of stations should be used and the analyses should be performed on different time scales. With a larger number of stations, the regional differences in drought occurrence could be studied in more detail, and the factors of changes could be identified. As climate scenarios suggest a further increase in precipitation variability 
and drought occurrence, such a result could benefit the agriculture and watery management system and, consequently, the economy as a whole.

\section{REFERENCES}

1. Ayanlade A., Radeny M., Morton, J. F., Muchaba T. (2018), Rainfall variability and drought characteristics in two agro-climatic zones: An assessment of climate change challenges in Africa. Science of The Total Environment, 630, 728-737. DOI: https://doi.org/10.1016/j.scitotenv.2018.02.196

2. Blenkinsop S., Fowler H. J. (2007), Changes in European drought characteristics projected by the PRUDENCE regional climate models. International Journal of Climatology, 27, 1595 - 1610. DOI: https://doi.org/10.1002/joc.1538

3. Bordi I., Frigio S., Speranza A., Sutera A. (2001), The analysis of the Standardized Precipitation Index in the Mediterranean area: regional patterns. Annali Di Geofisica, 44, 979 - 993. DOI: https://doi.org/10.4401/ag-3550

4. Cindrić K., Kalin L. (2012), Analiza mogućnosti i prognoze suše na području Hrvatske. Hrvatske vode, 79/80(20), 43-50. (in Croatian)

5. Cindrić K., Pasarić Z., Gajić-Čapka M. (2010), Spatial and temporal analysis of dry spells in Croatia. Theoretical and Applied Climatology, 102(1-2), 171-184. DOI: 10.1007/s00704-010-0250-6

6. Cindrić K., Telišman-Prtenjak M., Herceg-Bulić I., Mihajlović D., Pasarić Z. (2016), Analysis of the extraordinary 2011/2012 drought in Croatia. Theoretical and Applied Climatology, 123(3), 503-522. DOI: https://doi.org/10.1007/s00704-014-1368-8

7. Espinosa L. A., Portela M. M., Rodrigues R. (2019), Spatio-temporal variability of droughts over past 80 years in Madeira Island. Journal of Hydrology: Regional Studies, 25, 100623, DOI: https://doi.org/10.1016/j.ejrh.2019.100623

8. Gajić-Čapka M. (1982), Varijabilnost prosječnog oborinskog režima šire zagrebačke regije. Rasprave, 17, 23-40. (in Croatian)

9. Gajić-Čapka M., Cindrić K. (2011), Secular trends in indices of precipitation extremes in Croatia, 1901-2008. Geofizika, 28, 293-312.

10. Gajić-Čapka M., Cindrić K., Pasarić Z. (2015), Trends in precipitation indices in Croatia, 1961-2010. Theoretical and Applied Climatology, 121(1-2), 167-177. DOI: https://doi.org/10.1007/s0070

11. Hayes M. J., Svoboda M. D., Wilhite D. A., Vanyarkho O. V. (1999), Monitoring the 1996 Drought Using the Standardized Precipitation Index. Bulletin of the American Meteorological Society, 80(3), 429-438. DOI: https://doi.org/10.1175/15200477(1999)080<0429:MTDUTS>2.0.CO;2

12. Juras J. (1995), Metode za procjenu vremenske promjenljivosti količina oborina. Doctoral thesis, Zagreb, Faculty of Science, University of Zagreb, 160. (in Croatian)

13. Juras J., Cindrić K. (2009), Prostorna razdioba SPI na području Jadrana za razdoblje od srpnja do rujna 2008. Jadranska meteorologija, 13, 54-58. (in Croatian)

14. Liu B., Yan Z., Sha J., Li S. (2017), Drought evolution due to climate change and links to precipitation intensity in the Haihe River Basin. Water 9(11), 878 DOI: 10.3390/w9110878

15. Livada I., Assimakopoulos V. D. (2007), Spatial and temporal analysis of drought in Greece using the Standardized Precipitation Index (SPI). Theoretical and applied climatology, 89(3-4), 143-153. https://doi.org/10.1007/s00704-005-0227-z 
16. Ljubenkov I., Bonacci O. (2011), Drought identification and determination on the island of Korčula. Hrvatske vode, 77, 181-194. (in Croatian)

17. Ljubenkov I., Cindrić Kalin K. (2016), Evaluation of drought using standardised precipitation and flow indices and their correlations on an example of Sinjsko polje. Građevinar, 68 (1), 135-143

18. Lloyd-Hughes B., Saunders M. A. (2002), A drought climatology for Europe. International Journal of Climatololgy. 22, 1571-1592. DOI: DOI: 10.1002/joc.846

19. Maradin M., Madžar I., Perutina I. (2014), Geografska raspodjela varijabilnosti padalina u Hrvatskoj i Bosni i Hercegovini. Hrvatski geografski glasnik, 76(2), 5-26. DOI: https://doi.org/10.21861/HGG.2014.76.02.01 (in Croatian)

20. Martins D. S., Raziei T., Paulo A. A., Pereira L. S. (2012), Spatial and temporal variability of precipitation and drought in Portugal. Natural Hazards and Earth System Sciences, 12, 1493-1501. DOI: 10.5194/nhess-12-1493-2012

21. McKee T. B., Doeskin N. J., Kleist J. (1995), Drought Monitoring with Multiple Time Scales. Conference of Applied Climatology, American Meteorological Society, Boston, 179-184.

22. Mihajlović D. (2006), Monitoring the 2003-2004 meteorological drought over Pannonian part of Croatia. International Journal of Climatology, 26, 2213-2225. DOI: https://doi.org/10.1002/joc.1366

23. Milković J. (1998), Oborina na otocima i obali. Voda na hrvatskim otocima, Zbornik radova, Hrvatsko hidrološko društvo, Hvar, 83-98. (in Croatian)

24. O'Gorman P. A, Schneider T. (2009), The physical basis for increases in precipitation extremes in simulations of 21 st-century climate change. Proceedings of the National Academy of Sciences of the USA, 106, 14773-14777. DOI: 10.1073/pnas.0907610106

25. Perčec Tadić M., Gajić-Čapka M., Zaninović K., Cindrić K. (2014), Drought vulnerability in Croatia. Agriculturae Conspectus Scientificus, 79 (1) 31-38

26. Potop V., Boroneanţ C., Možný M., Štěpánek P., Skaláket P. (2014), Observed spatiotemporal characteristics of drought on various time scales over the Czech Republic. Theoretical and Applied Climatology, 115(3-4), 563-581. DOI: https://doi.org/10.1007/s00704-013-0908-y

27. Salehnia N., Alizadeh A., Sanaeinejad H., Bannayan M., Zarrin A., Hoogenboom G. (2017), Estimation of meteorological drought indices based on AgMERRA precipitation data and station-observed precipitation data. Journal of Arid Land, 9, 797-809. DOI: https://doi.org/10.1007/s40333-017-0070-y

28. Santos J. F., Pulido-Calvo I., Portela M. M. (2010), Spatial and temporal variability of droughts in Portugal. Water Resources Research, 46, W03503. DOI: 10.1029/2009WR008071

29. Šegota T. (1969), Sekularne fluktuacije padaline u Zagrebu. Geografski glasnik, 31, 5-55. (in Croatian)

30. Šegota T., Filipčić A. (2003), Köppenova podjela klima i hrvatsko nazivlje. Geoadria, 8(1), 17-37. (in Croatian)

31. Tadić L., Dadić T., Bosak B. (2015), Comparison of different drought assessment methods in continental Croatia. Građevinar, 67(1), 11-22. DOI: https://doi.org/10.14256/JCE.1088.2014 